Postmenozal Kadınlarda Visseral Adipozite İndeksi ve Aşırı Aktif Mesane: Yeni Bir Risk Belirteci

\title{
Visceral Adiposity Index and Overactive Bladder in Postmenopausal Woman: A Novel Predictive Risk Factor
}

\author{
Hüseyin Eren1, Mustafa Ozan Horsanalı², Eyüp Dil1, Emin Özbek ${ }^{3}$ \\ ${ }^{1}$ Recep Tayyip Erdoğan Üniversitesi Tıp Fakültesi Üroloji Anabilim Dalı, Rize, Türkiye \\ ${ }^{2}$ Recep Tayyip Erdoğan Üniversitesi Eğitim Ve Araștırma Hastanesi Üroloji Kliniği, Rize, Türkiye \\ ${ }^{3}$ İstanbul Üniversitesi Cerrahpaşa Tıp Fakültesi, İstanbul, Türkiye
}

\section{$\ddot{O} Z$}

AMAÇ: 45 yaş üstü postmenopozal kadın hastalarda visseral adipozite indeksi (VAI) ile aşırı aktif mesane semptomları arasındaki ilişkiyi araştırmak.

METARYAL ve METOD: Mart 2017-Aralık 2017 tarihleri arasında aşırı aktif mesane semptomları olan 76 postmenopozal kadın hasta değerlendirildi. Antropometrik veriler, serum kolesterol düzeyleri, açlık glukoz seviyeleri, ürodinamik bulgular ve OAB-8 formu kayıt edildi. VAI cinsiyete özgü formüle göre hesapland. Hastalar VAI seviyelerine göre üç gruba ayrıldı. VAI ile aşırı aktif mesane semptomları arasındaki ilişki ürodinamik sonuçlar ve $O A B-8$ skoru açısından istatiksel olarak karşılaş̧ırıldı.

BULGULAR: Hastaların yaş ortalaması $57.2 \square 8.3 \mathrm{yll}$, ortalama vücut kitle indeksi (VKI) $32.3 \square 2.8 \mathrm{~kg} / \mathrm{m} 2 \mathrm{idi}$. Gruplar arasında Pabd, post miksiyonel rezidü idrar miktar (PMRI), maksimum mesane kapasitesi (MMK) ve OAB-8 sorgulama formu skoru açısından anlamlı fark bulundu. VAI ile PMRI, detrüsor aşırı aktivitesi (DAA), idrar sıklı̆̆l, urge inkontinans, noktüri ve OAB-8 skoru arasinda pozitif korelasyon, MMK ve ilk işeme arzusu açısından negatif korelasyon tesbit edildi.

SONUÇ: VAI düzeyi yüksek olan hastalarda daha fazla aşırı aktif mesane semptomu olduğunu ve daha kötü ürodinamik bulguları olduğunu gözlemledik. VAI ayrıca aşırı aktif mesane semptomlarını öngörmede bir belirteç olarak kullanılabilir.

Anahtar kelimeler: Obezite; Aşırı aktif mesane; Üriner inkontinans; Visseral Adipozite İndeksi; Bel çevresi; Detrusör aşırı aktivitesi

\begin{abstract}
INTRODUCTION: To investigate the association between visceral adiposity index (VAI) and overactive bladder $(O A B)$ symptoms in postmenopausal female patients aged over 45 years.
\end{abstract}

MATERIALS and METHODS: Between March 2017 and December 2017, 76 postmenopausal female patient with $O A B$ symptoms were evaluated. Anthropometric indices serum cholesterol levels, fasting glucose levels, urodynamic findings and $O A B-8$ scores were recorded. VAI was calculated according to gender-specific formula. Participants were divided into three groups according to VAI levels. The relationship between VAI and OAB symptoms were statistically compared in terms of urodynamic outcomes and OAB-8 scores.

RESULTS: Mean age of the patients were $57.2 \square 8.3$ years and mean BMI was $32.3 \square 2.8 \mathrm{~kg} / \mathrm{m} 2$. Statistical significance was observed in terms of abdominal pressure (Pabd), post voiding residual urine mounts $(P V R)$, maximum bladder capasity $(M B C)$ and $O A B-8$ scores between groups. VAI correlated positively with $P V R$, detrusor overactivity (DOA), urinary frequency, urge incontinence, nocturia and $O A B-8$ scores whereas a negative correlation existed $M B C$ and first desire to void.

CONCLUSIONS: We observed that patients with higher levels of VAI had more OAB symptoms and worse urodynamic findings.VAI may also be used as a marker for predicting overactive bladder symptoms.

Keywords: Obesity; Overactive bladder; Urinary Incontinence; Visceral Adiposity Index; Waist Circumference; Detrussor overactivity

Iletişim / Correspondence:

Dr. Hüseyin Eren

Recep Tayyip Erdoğan Üniversitesi Tip Fakültesi Üroloji Anabilim Dall, Rize, Türkiye

E-mail: huseyin.eren@erdogan.edu.tr

Başvuru Tarihi: 01.07.2019

Kabul Tarihi: 17.07.2019 


\section{INTRODUCTION}

According to the International Continence Society (ICS), overactive bladder (OAB) is determined as a urinary urgency, usually accompanied by increased daytime frequency and nocturia, with urinary incontinence or without, in the absence of urinary tract infection or other detectable disease causing distress and negative impact on a person's quality of life (1). International populationbased studies have reported prevalence rates of $\mathrm{OAB}$ approximately $12 \%(6,7)$ and it rises $17 \%$ in patients aged 40 and over (2). OAB symptoms are not only disturbes patients but also have a significant negative impact on many aspects of the lives of individuals who represent a particularly effective health burden in terms of quality of life and productivity (3). It is known that obesity is a strong risk factor for OAB. Several population-based studies found that increased body mass index (BMI) could trigger symptomes of $\mathrm{OAB}(4,5)$.

The increasing prevalence of obesity and the obesity-related complications are health problems growing in developed countries (6). Although obesity was often described as BMI, previous studies showed that abdominal fat distribution might be a more prominent marker of obesity-related pathological features (7). The adipose tissue is mainly deposited into subcutaneous and visceral compartments. Visceral fat tissue consists mainly from omental fat and mesenteric fat. They have a higher metabolic activity than subcutaneous adipose tissue (8). Visceral adipose tissue has endocrine, metabolic, and immunological functions. These endocrine, metabolic and immunologic functions cause pathogenesis of the pro-inflammatory, procoagulant state of metabolic syndrome associated with insulin resistance (8). Visceral adipose index (VAI) is a new mathematical model that predicts visceral adiposity based on anthropometric and lipid profiles. It is a reliable formula of cardiometabolic risk which is useful indicator of visceral fat function without using costly and inappropriate imaging studies (9). In the present study, we aimed to evaluate the relationship between VAI and OAB symptoms with or without urinary incontinence.

\section{MATERIALS and METHODS}

In the present study, we evaluate patient charts of postmenopausal patients who had urodynamic study by clinician's preferences with $\mathrm{OAB}$ symptoms $(n=76)$, retrospectively. The collected data was recorded between March to December 2017. All patients were over 45-years-old. Female patients with a complete antropometric indices, incontinence, urodynamic study datas and laboratory results including serum cholesterol, fasting glucose were included study. Detailed medical histories of all patients were obtained before the study. Height, weight, and waist circumference (WC) were measured. BMI was computed by the formula as the ratio of weight to the square of height $(\mathrm{kg} / \mathrm{m} 2)$. WC was measured on the line between the iliac crest and the lower costal margin parallel to the ground after subjects exhaled.

Each patient filled out OAB questionnaire-8 Turkish validated short form and all datas were recorded. Inclusion criterias were age over 45, postmenouposal female gender, OAB symptoms with or without urinary incontinence, and available urodynamic study. Exclusion criterias were pregnancy, alcohol intake, bladder cancer history, previous incontinence surgery, presence of neurological disease, urinary infection, bladder stone, pelvic radiotherapy history and taking of estrogen therapy $(n=54)$. VAI was calculated according to gender-specific formula in figure-1(9).

Figure 1. Visceral adiposity index formula for female patients

$$
\begin{gathered}
\text { Females: VAI }=\left(\frac{\mathrm{WC}}{36.58+(1.89 \times \mathrm{BMI})}\right) \\
\times\left(\frac{\mathrm{TG}}{0.81}\right) \times\left(\frac{1.52}{\mathrm{HDL}}\right)
\end{gathered}
$$

VAI: Visceral adiposity index; WC: Waist circumference; BMI: Body mass index; TG: Trigliseride; HDL: High- density lipoprotein

Patients were divided into three groups according to VAI levels such as standard 1-9 (group 1), slightly high 10-14 (group 2), and high 15-30 (group 3) (10).

Urodynamic studies were performed accorindg to good urodynamics principels. The urodynamic study 
consists of free flow uroflowmetry, filling cystometry in semi-sitting position, stress urine leak test and pressure-flow study. The bladder was filled with saline at room temperature at a filling rate of 30 $\mathrm{ml} / \mathrm{min}$ to prevent the detrussor overactivity due to filling rate. Peri-anal surface electromyography activity was monitored in both the filling and pressure flow phases of the urodynamic study. Abdominal pressure, post voiding residual urine (PVR), bladder capacity, detrusor over activity (DOA) and first desire to void parameters was recorded.

All statistical analyses were conducted by SPSS 17.0 statistical package program. Categorical variables were demonstrated as frequencies and percentages, continuous variables were demonstrated by means $\square$ standard deviation. One way- ANOVA test was used to compare groups and post hoc Tukey test was used to examine the differences between groups. Pearson correlation analysis was used to test correlation between VAI and groups. A p value of $<0.05$ was set for a statistical significance level.

\section{RESULTS}

Seventy-six postmenopausal female patient aged over 45-years were included in the study. Mean age of the patients were $57.2 \pm 8.3$ years and mean BMI was $32.3 \pm 2.8 \mathrm{~kg} / \mathrm{m} 2$. Antropometric incides and laboratory characteristics of patients were summarized in (Table 1).

Thirty two (42.1\%) patients had standard, 24 (31.6\%) patients slightly high and 20 (26.3\%) patients had high VAI levels. Although 6 (7.9\%) of all patients were smoker, $70(92.1 \%)$ were nonsmoker. Thirty-three (43.4\%) patients have frequency, 19 (25\%) patients have urge urinary incontinence and $13(17.1 \%)$ patients have nocturnal symptoms. Urodynamic study results for Pabd (group 1 to 2), PVR (group 1 to 3), and maximum bladder capacity (MBC) (group 1 to 2) parameters were statistically significantly different between groups (Table 2).
Table 1. Antropometric characteristics and laboratory results of all patients Characteristics

\begin{tabular}{|c|c|}
\hline $\begin{array}{l}\text { Age, years, mean } \pm \text { SD } \\
\text { (range) }\end{array}$ & $\begin{array}{l}57.2 \pm 8.3 \\
(45-82)\end{array}$ \\
\hline $\begin{array}{l}\text { Naist circumference, } \mathrm{cm} \text {, mean } \pm \mathrm{SD} \\
\text { (range) }\end{array}$ & $\begin{array}{l}116.276 \pm 4.0898 \\
(90-139)\end{array}$ \\
\hline $\begin{array}{l}\mathrm{BMI}, \mathrm{kg} / \mathrm{m}^{2}, \text { mean } \pm \mathrm{SD} \\
\text { (range) }\end{array}$ & $\begin{array}{l}32.3623 \pm 2.85448 \\
(28.89-40.40)\end{array}$ \\
\hline $\begin{array}{l}\text { Glucose } \mathrm{mg} / \mathrm{dL} \text {, mean } \pm \mathrm{SD} \\
\text { (range) }\end{array}$ & $\begin{array}{l}128.43 \pm 41.056 \\
(101-366)\end{array}$ \\
\hline $\begin{array}{l}\text { Total cholesterol } \mathrm{mg} / \mathrm{dL} \text {, mean } \pm \mathrm{SD} \\
\text { (range) }\end{array}$ & $\begin{array}{l}197.21 \pm 43.898 \\
(116-312)\end{array}$ \\
\hline $\begin{array}{l}\text { Trigliseride } \mathrm{mg} / \mathrm{dL} \text {, mean } \pm \mathrm{SD} \\
\text { (range) }\end{array}$ & $\begin{array}{l}177.42 \pm 70.897 \\
(52-391)\end{array}$ \\
\hline $\begin{array}{l}\mathrm{HDL} \text { - cholesterol mg/ dL, mean } \pm \mathrm{SD} \\
\text { (range) }\end{array}$ & $\begin{array}{l}40.30 \pm 8.507 \\
(30-63)\end{array}$ \\
\hline $\begin{array}{l}\mathrm{LDL} \text { - cholesterol mg/ dL, mean } \pm \text { SD } \\
\text { (range) }\end{array}$ & $\begin{array}{l}136.20 \pm 38.216 \\
(56-276)\end{array}$ \\
\hline
\end{tabular}

A urodynamic DOA rate was $11.8 \%(n=9 / 76)$ in the in the whole group. DAO recorded in $3.1 \%(n=1), 12.5 \%(n=3)$, and $25 \%(n=5)$ of patients for Group 1, Group 2 and Group 3, respectively. Recorded urodynamic DOA and OAB-8 scores were statistically significantly higher in group 3 than group 1 and 2 (Table 2). Positive correlation was found between groups in terms of PVR, DOA, urinary frequency, urge incontinence, nocturia and OAB-8 scores parameters in Pearson correlation test, and negative correlation was found in MBC and first desire to void in urodynamic study (Table $3)$.

\section{DISCUSSION}

The underlying pathophysiology of OAB is still unclear, but it may be due to abnormalities in the detrussor, spontaneous motor activity abnormalities, triggered urgency and neurotransmitter release from urothelium by central mechanisms, especially cerebral white matter changes in prefrontal regions of the brain. The urothelium-suburothelium compartment of the bladder has a high metabolic activity and it is considered to responsible with mechanosensory transduction (11). But, the underlying pathology and relationship between obesity and $\mathrm{OAB}$ is not clear and it is still controversial. 


\begin{tabular}{|c|c|c|c|}
\hline & Group 1 & Group 2 & Group 3 \\
\hline Pdet, $\left(\mathrm{cm} \mathrm{H}_{2} \mathrm{O}\right)$, mean \pm SD & $18.05 \pm 13.7$ & $18.9 \pm 12.6$ & $16.2 \pm 15.5$ \\
\hline Pves, $\left(\mathrm{cm} \mathrm{H} \mathrm{H}_{2} \mathrm{O}\right)$, mean \pm SD & $19.8 \pm 14,5$ & $27.8 \pm 19.6$ & $24.8 \pm 13.5$ \\
\hline Pabd, $\left(\mathrm{cm} \mathrm{H}_{2} \mathrm{O}\right)$, mean \pm SD & $7.2 \pm 8.5^{b}$ & $15.1 \pm 15.1$ & $8.8 \pm 3.8$ \\
\hline $\begin{array}{r}\text { DOA, } n(\%) \\
\text { Absent } \\
\text { Present }\end{array}$ & $\begin{array}{c}31(96.9 \%) \\
1(3.1 \%)\end{array}$ & $\begin{array}{l}21(87.5 \%) \\
3(12.5 \%)\end{array}$ & $\begin{array}{l}15(75 \%) \\
5(25 \%)\end{array}$ \\
\hline PVR $(m L)$, mean \pm SD & $60.1 \pm 66.7^{a}$ & $85.4 \pm 90.6$ & $153.5 \pm 139.3$ \\
\hline ALPP $(m m H g)$, mean \pm SD & $28.6 \pm 28.8$ & $31.8 \pm 17.5$ & $27.9 \pm 26.6$ \\
\hline VLPP $(m m H g)$, mean $\pm S$ & $34.03 \pm 27.8$ & $38.2 \pm 21.5$ & $34.4 \pm 27.08$ \\
\hline $\mathrm{MBC}(\mathrm{mL})$, mean $\pm \mathrm{SD}$ & $505.6 \pm 207.3^{b}$ & $444.4 \pm 202.4$ & $351 \pm 168.5$ \\
\hline OAB-8 Score, mean \pm SD & $11.03 \pm 6.02^{\mathrm{a}}$ & $14.7 \pm 7.2$ & $19.05 \pm 9.9$ \\
\hline \multicolumn{4}{|c|}{$\begin{array}{l}\text { DOA: Detrussor overactvity; PVR: Post Voiding residual urine; ALPP: Abdominal Leak Point Pressure; VLPP: Valsalva Leak Point } \\
\text { Pressure; MBC: Maximum Bladder Capacity } \\
\text { a significantly different between group } 1 \text { and } 3,^{b} \text { significantly different between grades } 1 \text { and } 2 . p<0.05 \text { is considered statistically } \\
\text { significant }\end{array}$} \\
\hline
\end{tabular}

\begin{tabular}{|c|c|c|c|c|c|c|c|c|c|}
\hline & VAI & $\mathrm{MBC}$ & PVR & DOA & $\begin{array}{l}\text { OAB-8 } \\
\text { score }\end{array}$ & FDV & UF & UUI & Nocturia \\
\hline VAI & 1 & & & & & & & & \\
\hline MBC & $\mathbf{r}: 0.140$ & 1 & & & & & & & \\
\hline PVR & $\mathrm{r}-0.404 * *$ & $\mathrm{r}-0.291 *$ & 1 & & & & & & \\
\hline DOA & $\mathrm{r} 0.346^{* * *}$ & $\mathrm{r}-0.275^{*}$ & r0.072 & 1 & & & & & \\
\hline OAB-8 score & r0.477** & $r-0.104$ & r0.399** & $\mathrm{r} 0.045$ & 1 & & & & \\
\hline FDV & $\mathrm{r}-0.235^{* *}$ & r0.452** & $r-0.055$ & $\mathrm{r}-0.217$ & $\mathrm{r}-0.220$ & 1 & & & \\
\hline UF & $\mathrm{r} 0.379 * *$ & $\mathrm{r}-0.110$ & $\mathrm{r} 0.200$ & $\mathrm{r} 0.132$ & $\mathrm{r} 0.069$ & $\mathrm{r}-0.227^{*}$ & 1 & & \\
\hline UUI & $\mathrm{r} 0.372 * *$ & $r-0.029$ & r0.348** & $\mathrm{r} 0.001$ & r0.792** & $\mathrm{r}-0.219$ & $\mathrm{r} 0.659 * *$ & 1 & \\
\hline Nocturia & $\mathrm{r} 0.298 * *$ & $\mathrm{r} 0.073$ & $\mathrm{r} 0.316 * *$ & $\mathrm{r} 0.072$ & $\mathrm{r} 0.722 * *$ & $r-0.099$ & $\mathrm{r} 0.519 * *$ & $\mathrm{r} 0.787 * *$ & 1 \\
\hline
\end{tabular}

Visceral adiposity index is used as one of the indicator of visceral obesity. In the present study high visceral adiposity index levels were associated with OAB symptomes. Patients with higher VAI levels have increased PVR, frequency and urge urinary incontinence than patients with lower VAI levels. Urodynamic DOA rate was incresead with incresing VAI. Although there are several studies reporting association between obesity and $\mathrm{OAB}$, to our best of knowledge this is the first study evaluating relationship between VAI as a marker of central obesity and postmenopausal female patients with $\mathrm{OAB}$.

BMI over 30 reported as an independent risk factor for OAB and DOA in some studies (13-16). In a study relationship between central and general obesity in terms of $\mathrm{OAB}$ and incontinance eavulated. 
In this tstudy central and general obesity cause urgency and urge incontinance in both gender, though over active baldder sydrome symptoms nopted only for female gender (12). VAI is a reliable marker of central obesity. Our results supports findings of previously reported studies (13). Patients with high VAI levels have increases $\mathrm{OAB}$ symptoms, in terms of urgency and urge incontinence. In the present study we revealed that VAI could be used as a predictive antorpometric marker for $\mathrm{OAB}$ for postmenopausal females.

The relation between excessive weight gain and urinary incontinence were reported in some studies. All these studies concluded that excessive weight gain may increase the pressure on the pelvic floor muscles. This may lead to weakeness of the urethral sphincter structure and cause urinary incontinence $(14,15)$. Excessive visceral fat tissue may cause bladder inflammation, possibly due to changes in neuroendocrine processes that can occur as urinary frequency and urgency. This suggests that the increase in visceral fat tissue may be a risk factor for stress urinary incontinence $(4,16)$. In a study with 83355 participants, overweight women found an increased risk of urinary incontinence compared to their weak counterparts. The risk incresed $3 \%$ for per kilogram weight gain and $7 \%$ for each kilogram per meters 2 for BMI. (17). In the present study, we support previous studies with positive correlation between VAI, urgency and urge incontinence.

In a study, 76 patients with LUTS were evaluated for pre and postoperative bariatric surgery. A statistically significant decrease in symptoms such as nocturia, urgency, stres urinary incontinence, frequency, unaware incontinence and, an increased quality of life scores were reported for women with LUTS at 6th week and 1st year after bariatric surgery (21). In the present study the mean BMI was $32.3 \square 2.8 \mathrm{~kg} / \mathrm{m} 2$. Patients with high BMI had higher symptoms scores and impaired urodynamic features. We consider that central obesity may have a role in underlying pathophysiology of OAB. As a result VAI may be a useful a marker for central obesity instead of BMI.

In a randomized control trial, 40 women with normal urodynamic results at baseline were examined by administering controlled weight loss as incontinence therapy. A statistically significant relation was reported with weight loss. Urodynamic findings were improved including decreased initial intravesical pressure, decreased intravesical pressure at maximum capacity and increased valsalva leak point pressure. For reason, present study also concludes that modification the risk factor changes the biological variant and intervenes in a reasonable mechanism (18). In present study we found similar results in terms of urodynamic findings. Patients with higher VAI levels, as an indicator of central obesity, have higher OAB-8 questionnaire scores, frequency, urge incontinence and nocturia. And also worse urodynamic findings such as increased PVR, DOA and first desire to void at low bladder filling.

Retrospective design and low number of patients were the most important limitations in the presnt study. We could also not explained the underlying pathophysiological mechanism between VAI and OAB. Histopathological changes on bladder wall or mucosa related to central obesity could not reveal. Although obesity is well known and modifiable risk factor for $\mathrm{OAB}$ in the literature, obesity related pathophysiological mechanism is still not clear.

\section{CONCLUSION}

We observed that patients with higher levels of VAI had more OAB symptoms and worse urodynamic findings. Therefore, VAI may be use as an indicator of central obesity and predictive marker for overactive bladder and follow-up VAI levels may be useful for the management of patients with overactive bladder.

\section{Conflict of interest}

Author declared no conflicts of interest

\section{REFERENCES}

1. Abrams P. Describing bladder storage function: overactive bladder syndrome and detrusor overactivity. Urology. 2003;62(5):28-37.

2. Milsom I, Abrams P, Cardozo L, Roberts R, Thüroff J, Wein A. How widespread are the symptoms of an overactive bladder and how are they managed? A population-based prevalence study. BJU international. 2001;87(9):760-6. 
3. Reynolds WS, Fowke J, Dmochowski R. The burden of overactive bladder on US public health. Current bladder dysfunction reports. 2016;11(1):813.

4. Link CL, Steers WD, Kusek JW, McKinlay JB. The association of adiposity and overactive bladder appears to differ by gender: results from the Boston Area Community Health survey. The Journal of urology. 2011;185(3):955-63.

5. Lawrence JM, Lukacz ES, Liu I-LA, Nager $\mathrm{CW}$, Luber KM. Pelvic floor disorders, diabetes, and obesity in women. Diabetes Care. 2007;30(10):2536-3541.

6. Ogden CL, Carroll MD, Curtin LR, Lamb MM, Flegal KM. Prevalence of high body mass index in US children and adolescents, 2007-2008. Jama. 2010;303(3):242-9.

7. Ohwaki K, Endo F, Hattori K. Visceral adipose tissue measured by computed tomography and highgrade prostate cancer after radical prostatectomy. International Journal of Obesity. 2015;39(11):165961.

\section{Galic S, Oakhill JS, Steinberg GR. Adipose}

tissue as an endocrine organ. Molecular and cellular endocrinology. 2010;316(2):129-39.

9. Amato MC, Giordano C, Galia M, Criscimanna A, Vitabile S, Midiri M, et al. Visceral adiposity index. Diabetes care. 2010;33(4):920-2.

10. Hu L, Huang X, You C, Li J, Hong K, Li P, et al. Prevalence of overweight, obesity, abdominal obesity and obesity-related risk factors in southern China. PloS one. 2017;12(9):e0183934.

11. Kumar V, Cross RL, Chess-Williams R, Chapple CR. Recent advances in basic science for overactive bladder. Current opinion in urology. 2005; 15(4):222-6.

12. Lai HH, Helmuth ME, Smith AR, Wiseman JB, Gillespie BW, Kirkali Z. Relationship between central obesity, general obesity, overactive bladder syndrome and urinary incontinence among male and female patients seeking care for their lower urinary tract symptoms. Urology. 2019;123:34-43.

13. Motamed N, Khonsari M, Rabiee B, Ajdarkosh H, Hemasi G, Sohrabi M, et al.
Discriminatory ability of visceral adiposity index (VAI) in diagnosis of metabolic syndrome: a population based study. Experimental and Clinical Endocrinology \& Diabetes. 2017;125(03):202-7.

14. Wesnes SL. Weight and urinary incontinence: the missing links. International urogynecology journal. 2014;25(6):725-9.

15. Dallosso H, McGrother C, Matthews RJ, Donaldson $\mathrm{M}$. The association of diet and other lifestyle factors with overactive bladder and stress incontinence: a longitudinal study in women. BJU international. 2003;92(1):69-77.

16. Dursun M, Otunctemur A, Ozbek E, Sahin S, Besiroglu H, Koklu I. Stress urinary incontinence and visceral adipose index: a new risk parameter. International urology and nephrology. 2014;46(12):2297-300.

17. Townsend MK, Danforth KN, Rosner B, Curhan GC, Resnick NM, Grodstein F. Body mass index, weight gain, and incident urinary incontinence in middle-aged women. Obstetrics \& Gynecology. 2007;110(2, Part 1):346-53.

18. Subak LL, Whitcomb E, Shen H, Saxton J, Vittinghoff E, Brown JS. Weight loss: a novel and effective treatment for urinary incontinence. The Journal of urology. 2005;174(1):190-5. 